\title{
CLASSIFICATION OF VEHICLE TYPES USING BACKPROPAGATION NEURAL NETWORKS WITH METRIC AND ECCENTRICITY PARAMETERS
}

\author{
Hendra Mayatopani ${ }^{1}$, Rohmat Indra Borman ${ }^{2 *}$, Wahyu Tisno Atmojo ${ }^{3}$, Arisantoso ${ }^{4}$ \\ 1,3Program Studi Sistem Informasi \\ Universitas Pradita \\ https://www.pradita.ac.id/ \\ hendra.mayatopani@pradita.ac.id,wahyu.tisno@pradita.ac.id \\ ${ }^{2}$ Fakultas Teknik dan Ilmu Komputer \\ Universitas Teknokrat Indonesia \\ https://teknokrat.ac.id/ \\ rohmat_indra@teknokrat.ac.id \\ ${ }^{4}$ Program Studi Informatika \\ Sekolah Tinggi Teknologi Informasi NIIT Jakarta \\ https://i-tech.ac.id/ \\ arisantoso@i-tech.ac.id \\ (*) Corresponding Author
}

\begin{abstract}
Abstrak
Salah satu upaya untuk mengurai kemacetan lalu lintas dengan menetapkan jalur khusus yang dapat dilalui oleh kendaraan roda dua, empat atau lebih. Dengan mampu mengenali jenis kendaraan dapat mengueangi kemacetan. Klasifikasi kendaraan berdasarkan citran membantu dalam memberikan informasi tentang jenis kendaraan. Penelitian ini bertujuan untuk mengklasifikasikan jenis kendaraan menggunakan algoritma jaringan syaraf tiruan backpropagation. Citra kendaraan dapat dikenali berdasarkan bentuknya, maka algoritma jaringan syaraf tiruan backpropagation akan didukung oleh parameter metrik dan eksentrisitas untuk melakukan ekstraksi ciri. Kemudian dari hasil ekstraksi ciri dengan parameter metrik dan eksentrisitas, objek tersebut akan diklasifikasikan menggunakan algoritma jaringan syaraf tiruan backpropagation. Hasil pengujian menunjukkan akurasi sebesar 87,5\%. Hal ini menunjukkan algoritma dapat melakukan klasifikasi dengan baik.
\end{abstract}

Kata kunci: backpropagation, metrik, eksentrisitas, jaringan syaraf tiruan, klasifikasi kendaraan

\begin{abstract}
One of the efforts to break down traffic jams is to establish special lanes that can be passed by two, four, or more wheeled vehicles. By being able to recognize the type of vehicle can reduce congestion. Citran based vehicle classification helps in providing information about the vehicle type. This study aims to classify the type of vehicle using a backpropagation neural network algorithm. The vehicle image can be recognized based on its shape, then the backpropagation neural network algorithm will be supported by metric and eccentricity parameters to perform feature extraction. Then from the results of feature extraction with metric parameters and eccentricity, the object will be classified using a backpropagation neural network algorithm. The test results show an accuracy of $87.5 \%$. This shows the algorithm can perform classification well.
\end{abstract}

Keywords: backpropagation, metrics, eccentricity, artificial neural network, vehicle classification

\section{INTRODUCTION}

A vehicle is a means used for transportation which is usually used in people's daily activities. The vehicles that are often used are land vehicles, such as cars, motorbikes, and buses. In recent years, the volume of vehicles in Indonesia has increased rapidly. According to data from the Central Statistics Agency (BPS), the number of all types of motorized vehicles, both passenger cars, buses, and freight cars in Indonesia in 2018 reached $146,858,759$ million (Himilda \& Johan, 2021). The increasing number of vehicles every year causes traffic jams on the highway as well as the entrances 
and exits of toll gates. The government makes efforts to prevent traffic congestion by establishing special lanes that may be passed by two, four, or more wheeled vehicles. By being able to recognize the type of vehicle can reduce congestion. So we need a vehicle classification based on its image that makes it easier to provide information about the type of vehicle.

Digital image processing is a field that studies how an image is formed, managed, and analyzed to obtain useful information from the image (Lee \& Tseng, 2018). The utilization of image processing can be used for classification. Image classification can be referred to as the process of grouping the pixels of an image into several classes so that each class can describe an entity that has recognizable characteristics (Dix \& Müller, 2021). By detecting certain objects the image can produce information that can be managed (Mulyanto, Borman, Prasetyawana, \& Sumarudin, 2020). The utilization of image processing can be used for classification. Image classification is the process of grouping pixels in an image into several classes so that each class can describe an entity with certain characteristics (Prasetyawan et al., 2018). Image classification can take advantage of artificial neural network algorithms. An artificial neural network is a computational method that mimics a biological neural network (Wiliani, Sani, \& Andyanto, 2019). This method uses basic non-linear calculations called neurons and is interconnected so that it resembles a human neural network (Hasanah \& Permatasari, 2020). One of the most popular artificial neural network algorithms used for classification is the backpropagation neural network (BNN) algorithm. BNN is a supervised type of training algorithm that has many layers (Setti \& Wanto, 2019). BNN uses the error output to change the value of its weights in the backward direction.

The BNN algorithm in several previous studies showed good results in classifying. Previous research that classified Indonesian-language books based on their covers used the backpropagation neural network algorithm (Purwanta, Adi, \& Dewi, 2020). From the results of testing the accuracy using one hidden layer and 15 neurons is $63.31 \%$. As for the 2 hidden layers with a combination of 15 and 35 neurons, the accuracy is $79.89 \%$. Another research regarding the development of applications that are used to identify the image of medicinal plants in the Gorontalo area using an artificial neural network using backpropagation (Latief \& Yusuf, 2018). From the evaluation results, the network architecture with the highest accuracy reaches $100 \%$ and the least number of iterations with 50 neurons in the hidden layer and 143 epochs. Further research is about classifying the image of Lombok's typical songket woven fabric by using an artificial neural network algorithm using backpropagation (Imran \& Efendi, 2020). This study shows that increasing the number of neurons can increase the amount of accuracy. Based on trials using 100 neurons, getting 100\% success can be classified.

This study aims to classify the types of vehicles (especially land vehicles), using a backpropagation neural network algorithm. The image of a vehicle can be recognized based on its shape. For this reason, in this paper, the backpropagation neural network algorithm will be supported by metric and eccentricity parameters to perform feature extraction. The metric and eccentricity parameters are used as feature extraction based on their shape so that they can distinguish the shape of one object from another. Then, from the results of feature extraction with metric and eccentricity parameters, the object will be classified using a backpropagation neural network algorithm.

\section{RESEARCH METHODS}

This research consists of several stages to research so that it can be carried out properly. These stages can be seen in Figure 1 below.

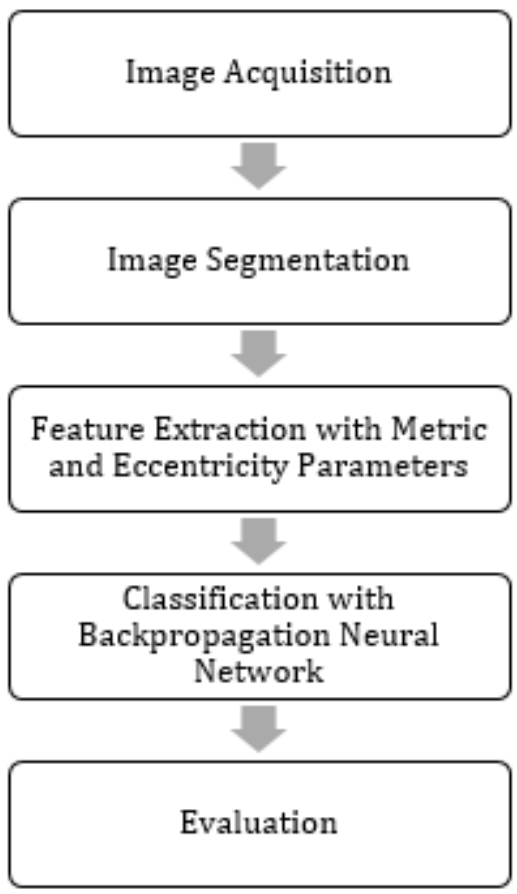

Figure 1. Research Stages

\section{Image Acquisition}

The first step is to collect beef images that are used as datasets. This is very important because the availability of datasets is a determining factor 
for image processing performance (Mulyanto, Jatmiko, Mursanto, Prasetyawan, \& Borman, 2021). The types of vehicles used in this study were motorcycles, cars, buses, and trucks. The dataset used is a dataset taken from the internet. The dataset distribution process uses a trial-and-error approach (Chen, Song, Liu, Yang, \& Li, 2020), which determines the structure of the model by dividing the data into 50\% training and 50\% testing. There are 160 images of vehicles that are sampled. So, the data used for training are 80 images and the data used for testing are 80 images with 20 images for each vehicle.

\section{Image Segmentation}

Image segmentation serves to separate one object from another. Separation is carried out based on territorial boundaries that have the same shape or arrangement. The output of this process is a binary image, where the desired object has a value of 1 (white color), while the background value is 0 (black color). Image segmentation in this paper uses the thresholding technique. Thresholding aims to find the right threshold value, to separate objects from the background (Wati, Haviluddin, Puspitasari, Budiman, \& Rahim, 2019). The thresholding process can use the formula:

$x=b * \operatorname{int}\left(\frac{w}{b}\right)$

$b=\operatorname{int}\left(\frac{256}{a}\right)$

The formula shows the value of the degree of gray before thresholding. While $\mathrm{x}$ shows the value of the degree of gray after thresholding.

\section{Feature Extraction with Metric and Eccentricity Parameters}

Feature extraction is a process to obtain distinguishing characteristics that distinguish an object from other objects. The extracted features are then used as parameters or input values to distinguish objects from one another at the classification stage. One of the characteristics that can be extracted is the shape feature. In extracting shape features using metric and eccentricity. Metric is a comparison value between the area and the circumference of an object. While eccentricity is a comparison value between the distance of the minor elliptical foci with the major elliptical foci of an object. The matrix and eccentricity values can be found with the following equation: $e=\sqrt{1-\frac{b^{2}}{a^{2}}}$

$M=\frac{4 \pi \times A}{C}$

Where $a$ is the minor axis and $b$ is the major axis. While $A$ is the area and $C$ is the circumference.

\section{Classification with Backpropagation Neural Network}

Backpropagation is a supervised learning algorithm that consists of an input layer, a hidden layer, and an output layer by changing the weights connected to each layer.

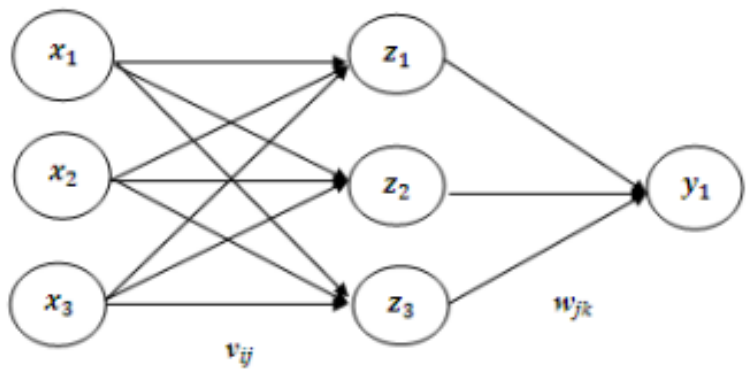

Figure 2. Neural Network Architecture

Figure 2 above is an example of BNN architecture which shows that $x_{1}, x_{2}, x_{3}$, are input layers, and $z_{1}, z_{2}, z_{3}$ are hidden layers. While $y_{1}$ is the output layer. Between the input layer to the hidden layer and the hidden layer to the output, layers are connected by their respective weights. The BNN model can use the following equation:

$y_{k}=f_{k}\left(\sum_{j=1}^{p} w_{j k} f_{j}\left(v_{0 j}+\sum_{i=1}^{n} x_{i} v_{i j}\right)+w_{0 k}\right)$.

\section{Evaluation}

The evaluation stage is the stage where testing will be carried out on the performance of the built model (Borman et al., 2018). This stage is the stage where the effectiveness of the developed algorithm will be tested. The classification results from the developed algorithm will be tested for accuracy. Accuracy is used so that it can be known to know the closeness of the test results or the average test results to the actual value. To test the accuracy using the following equation:

Accuracy $=\frac{T P}{C P} \times 100 \%$

Where, CP is the number of correct predictions, namely the number of test data records 
predicted by the class using the identification method and the results are the same as the actual class. While TP is the total number of predictions, where the total number is predicted by the class.

\section{RESULTS AND DISCUSSION}

In classifying vehicle types with the BNN algorithm, a training process is carried out first. There are 4 categories of vehicles, namely: motorcycles, cars, buses, and trucks. The dataset used is 160 vehicle images. The data used for training are 80 images and the data used for testing are 80 images with 20 images for each vehicle. After the dataset has been collected, the next step is to prepare for training. Training and testing are carried out using the Matlab application. This stage begins with image segmentation. Image segmentation used is thresholding. This process converts image data into binary data to facilitate the feature extraction process. At this stage, the image will be converted into a binary image. The results of image segmentation carried out on one of the image samples that have been carried out can be seen in Figure 3.

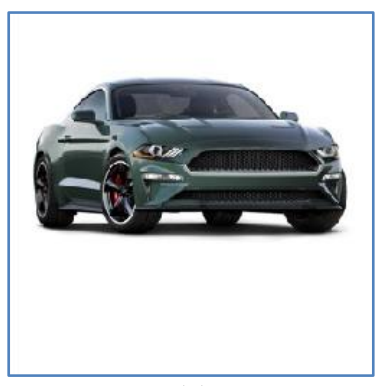

(a)

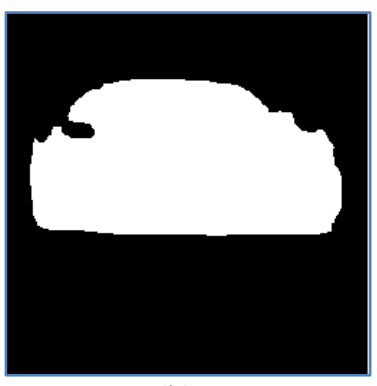

(b)
Figure 3. (a) Original Image and (b) Resulting Binary Image

As seen in Figure 3, (a) shows the original image and (b) shows the results of segmentation. The result of the segmentation is a binary image consisting of images with values 1 and 0 . The next stage is to perform feature extraction based on its shape with metric and eccentricity parameters. The result of image segmentation is then identified the vehicle object to be classified.

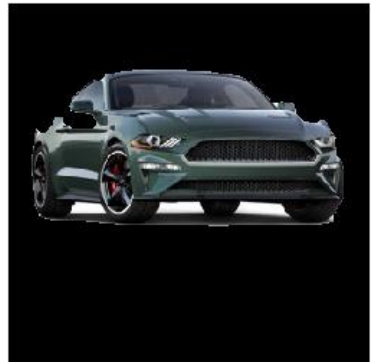

Figure 4. Results of the Segmentation Process

In Figure 4 it can be seen that the object to be classified has been detected as a result of the segmentation stage. Then the information contained in the object is matched with other objects for identification. After the feature extraction is carried out, the BNN algorithm architecture is built to perform classification. The BNN algorithm architecture is implemented in the Matlab application. The architecture of the BNN algorithm used for the training that has been carried out can be seen in Figure 5 .

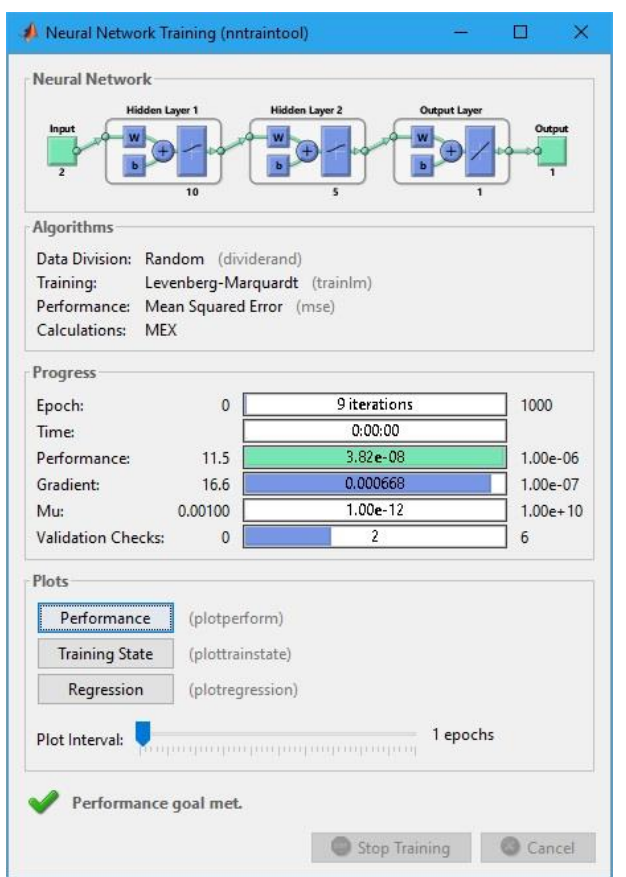

Figure 5. Display of the BNN Algorithm Training Process in the Matlab Application

Figure 5 is the architecture of the BNN algorithm, where the number of epochs used is 9 iterations. Furthermore, testing is carried out by implementing the BNN algorithm architecture in a GUI application with Matlab. The display of the vehicle type classification application that was built can be seen in Figure 6. 


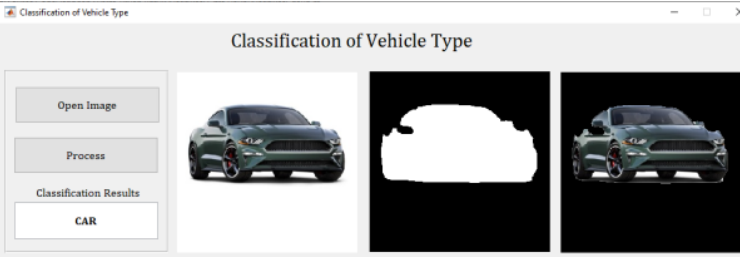

Figure 6. Vehicle Type Classification Application GUI Display

It can be seen in Figure 6, the GUI application was developed to classify vehicles based on the input test image. After the GUI application has been built, further testing is carried out on the accuracy of the developed algorithm. The system will be tested for accuracy using equation (6) which has been discussed previously. The test data used are 80 test data. There are 4 classes or categories of vehicles used, namely motorbikes, cars, buses, and trucks. Each class uses 20 pictures. All test images will be matched with the predicted results. Table 1 below is the test results from the classification results of the 4 classes of vehicle types used.

Table 1. Accuracy Test Result

\begin{tabular}{lccc}
\hline $\begin{array}{c}\text { Transportation } \\
\text { type }\end{array}$ & $\begin{array}{c}\text { Number of } \\
\text { Correct } \\
\text { Predictions }\end{array}$ & $\begin{array}{c}\text { Total } \\
\text { Number of } \\
\text { Predictions }\end{array}$ & $\begin{array}{c}\text { Accur } \\
\text { acy }\end{array}$ \\
\hline Motorcycle & 19 & 1 & 95 \\
\hline Car & 19 & 1 & 95 \\
\hline Bus & 16 & 4 & 80 \\
\hline Truck & 16 & 4 & 80 \\
\hline & 70 & 10 & 87.5 \\
\hline
\end{tabular}

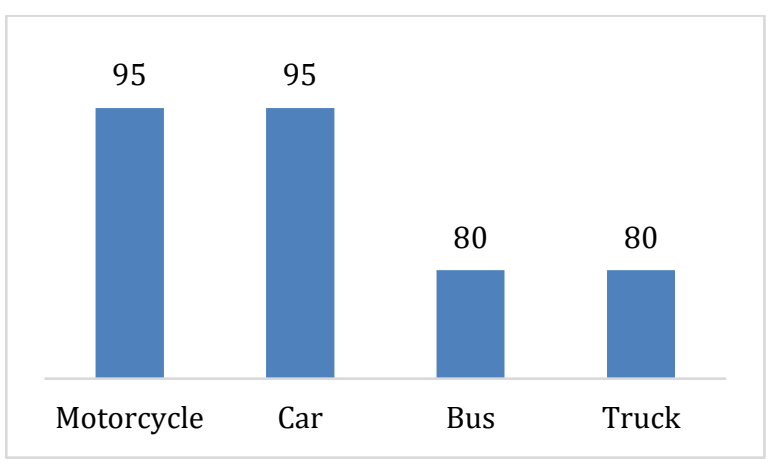

Figure 7. Graph of Accuracy Test Results

The graph in Figure 7 shows that the average accuracy of the accuracy test results obtained from the percentage of identification accuracy is $87.5 \%$. While the average identification error is $2.5 \%$. This is due to several factors, including: (1) the amount of training data and test data is still very small; (2) Feature extraction based on its shape, the accuracy will be high if the extracted image displays the image clearly; (3) for identification with images with various background algorithms have difficulty. If you look at the average accuracy obtained from the identification accuracy percentage of $87.5 \%$, it shows good accuracy, with percentage classification accuracy: Good, with a value of 76\%-100\%; Enough, with a value of $56 \%$ $75 \%$; Less Good, with a value of $40 \%-55 \%$, while Less Good, has a value of less than $40 \%$ (Borman \& Purwanto, 2019).

\section{CONCLUSIONS AND SUGGESTIONS}

\section{Conclusion}

This research is to classify the types of vehicles using a backpropagation neural network. Feature extraction uses metric parameters and eccentricity, which performs feature extraction based on its shape so that it can distinguish the shape of an object from other objects. Then the results of feature extraction will be classified using a backpropagation neural network algorithm that performs supervised learning consisting of an input layer, a hidden layer, and an output layer by changing the weights connected to each layer. The results of the test showed an accuracy of $87.5 \%$. This shows the algorithm can perform classification well.

\section{Suggestion}

To improve future research, several suggestions can be made. Improvements made include: (1) increasing the number of training data and test data; (2) using feature extraction not only shape, can add color and texture feature extraction; (3) using deep learning algorithms to get better feature extraction and identification.

\section{REFERENCES}

Borman, R. I., \& Purwanto, Y. (2019). Impelementasi Multimedia Development Life Cycle pada Pengembangan Game Edukasi. JEPIN (Jurnal Edukasi Dan Penelitian Informatika)(Jurnal Edukasi Dan Penelitian Informatika), 5(2), 119-124.

Borman, R. I., Putra, Y. P., Fernando, Y., Kurniawan, D. E., Prasetyawan, P., \& Ahmad, I. (2018). Designing an Android-based Space Travel Application Trough Virtual Reality for Teaching Media. Proceedings of the 2018 International Conference on Applied Engineering, ICAE. https://doi.org/10.1109/INCAE.2018.85793 94

Chen, Y., Song, L., Liu, Y., Yang, L., \& Li, D. (2020). A Review of the Artificial Neural Network Models for Water Quality Prediction. Applied Sciences, 10(5776), 1-49. 
Dix, S., \& Müller, P. (2021). Digital Image Processing Methods for The Evaluation of Optical Anisotropy Effects in Tempered Architectural Glass Using Photoelastic Measurements. Glass Structures \& Engineering, 6(1), 3-19. https://doi.org/10.1007/s40940-02000145-3

Hasanah, S. H., \& Permatasari, S. M. (2020). Backpropagation Artificial Neural Network Classification Method in Statistics Students of Open University. BAREKENG: Jurnal IImu Matematika Dan Terapan, 14(2), 243-252.

Himilda, R., \& Johan, R. A. (2021). Klasifikasi Jenis Kendaraan Menggunakan Metode Extreme Learning Machine (Vehicle Classification Using Extreme Learning Machine Method). JTIM: Jurnal Teknologi Informasi Dan Multimedia, 2(4), 237-243.

Imran, B., \& Efendi, M. M. (2020). The Implementation of Extraction Feature Using Glcm And Back-Propagation Artificial Neural Network to Clasify Lombok Songket Woven Cloth. Jurnal TECHNO Nusa Mandiri, 17(2), 131-136.

Latief, M., \& Yusuf, R. (2018). Gorontalo Medicinal Plants Image Identification System Using Artificial Neural Network with Back Propagation. IJITEE, 2(2), 45-50.

Lee, S. L., \& Tseng, C. C. (2018). Digital Image Sharpening Using Integral Image Representation and Laplacian Operator. 2018 IEEE International Conference on Consumer Electronics-Taiwan, ICCE-TW 2018, 31-32. https://doi.org/10.1109/ICCEChina.2018.8448488

Mulyanto, A., Borman, R. I., Prasetyawana, P., \& Sumarudin, A. (2020). 2D Lidar and Camera Fusion for Object Detection and Object Distance Measurement of ADAS Using Robotic Operating System ( ROS ). JOIV: International Journal on Informatics Visualization, 4(4),
231-236.

Mulyanto, A., Jatmiko, W., Mursanto, P., Prasetyawan, P., \& Borman, R. I. (2021). A New Indonesian Traffic Obstacle Dataset and Performance Evaluation of YOLOv4 for ADAS. Journal of ICT Research and Applications, 14(3), 286-298. https://doi.org/10.5614/itbj.ict.res.appl.202 1.14.3.6

Prasetyawan, P., Ahmad, I., Borman, R. I., Ardiansyah, A., Pahlevi, Y. A., \& Kurniawan, D. E. (2018). Classification of the Period Undergraduate Study Using Backpropagation Neural Network. Proceedings of the 2018 International Conference on Applied Engineering, ICAE 2018. https://doi.org/10.1109/INCAE.2018.85793 89

Purwanta, I. P. B. D., Adi, C. K., \& Dewi, N. P. N. P. (2020). Backpropagation Neural Network for Book Classification Using the Image Cover. International Journal of Applied Sciences and Smart Technologies, 2(2), 179-196.

Setti, S., \& Wanto, A. (2019). Analysis of Backpropagation Algorithm in Predicting the Most Number of Internet Users in the World. JOIN (Jurnal Online Informatika), 3(2), 110115. https://doi.org/10.15575/join.

Wati, M., Haviluddin, Puspitasari, N., Budiman, E., \& Rahim, R. (2019). First-order Feature Extraction Methods for Image Texture and Melanoma Skin Cancer Detection. Journal of Physics: Conference Series, 1230(1). https://doi.org/10.1088/17426596/1230/1/012013

Wiliani, N., Sani, A., \& Andyanto, A. T. (2019). Klasifikasi Kerusakan Dengan Jaringan Syaraf Backpropagation pada Permukaan Solar Panel. Jurnal Ilmu Pengetahuan Dan Teknologi Komputer, 5(1), 89-94. 